\title{
Variasi Basis Salep Minyak Kemiri (Aleurites moluccana) dan Uji Daya Penyembuhannya pada Luka Kelinci
}

\section{(Base Variations of The Candlenut Oil Ointment (Aleurites moluccana) and The Healing Potential Test on Wounds in Rabbits)}

\author{
PAULINA V. Y. YAMLEAN ${ }^{1 *}$, EDWIN DE QUELJOE ${ }^{1}$, WIDDHI BODHI ${ }^{2}$ \\ ${ }^{1}$ Program Studi Farmasi, FMIPA Universitas Sam Ratulangi \\ ${ }^{2}$ Program Studi Kedokteran, Fakultas Kedokteran Universitas Sam Ratulangi \\ *Penulis korespondensi, Hp : 081356337914 \\ e-mail : olan_0506@yahoo.co.id
}

Diterima, 15 November 2018, Disetujui 17 Desember 2018

\begin{abstract}
Abstrak: Kemiri di Indonesia masih terbatas penggunaannyasecara tradisional seperti bumbu masak dan obat tradisional. Penelitian tentang minyak Kemiri belum banyak dilakukan. Tujuan penelitian ini ialah membuat variasi basis salep terhadap mutu sediaan salep minyak kemiri $12,5 \%$ dan Uji daya penyembuhannya terhadap luka terbuka pada kelinci yang terinfeksi bakteri Staphylococcus aureus. Metode penelitian ini ialah eksperimen laboratorium menggunakan 3 variasi basis salep yaitu basis hidrokarbon, basis absorpsi dan basis larut air dengan larutan uji minyak kemiri 12,5\%. Hasil penelitian menunjukkan uji mutu salep dengan tiga variasi basis salep memenuhi syarat uji organoleptik, uji homogenitas, dan uji $\mathrm{pH}$, tetapi salep minyak kemiri 12,5\% dengan basis hidrokarbon tidak memenuhi syarat daya sebar. Hasil uji Anova menunjukan tidak ada perbedaan signifikan antara variasi basis salep dan besar luka penyembuhan. Hal ini menunjukan bahwa ketiga variasi basis salep minyak Kemiri 12,5\% dapat digunakan dalam penyembuhan luka terbuka pada kelinci (Oryctolagus cuniculus) yang terinfeksi bakteri Staphylococcus aureus.
\end{abstract}

Kata kunci: Minyak kemiri, variasi basis salep, kelinci.

\begin{abstract}
Candlenut plant in Indonesia is still limited to traditional uses such as cooking spices and traditional medicines. Only a few research has been done on Candlenut oil. The purpose of this study is to make ointment base variations toward the quality of Candlenutoil ointment with $12.5 \%$ concentration andits healing potential teston open wounds in rabbits infected with the Staphylococcus aureus bacteria. This research method is a laboratory experiment using 3 variations of base ointment namely hydrocarbon base, absorption base and water soluble base with Candlenut oil test solution of $12.5 \%$. The results showed the quality test of the ointment with three variations of ointment base fulfilled the requirements of organoleptic test, homogeneity test, and $\mathrm{pH}$ test, but Candlenutoil ointment of $12.5 \%$ with hydrocarbon base did not meet the scattering power requirement. The results of the ANOVA test showed no significant difference between the base variations of the ointment and the size of wound healing. This shows that the three variations of the $12.5 \%$ Candlenut oil ointment base can be used in healing open wounds on rabbits (Oryctolagus cuniculus) infected with the Staphylococcus aureus bacteria.
\end{abstract}

Keywords: Candlenut oil, ointment base variations, rabbit. 


\section{PENDAHULUAN}

PEMANFAATAN kemiri di Indonesia masih terbatas pada penggunaan tradisional seperti bumbu masak dan obat tradisional. Tanaman kemiri secara empiris biasanya dibakar dengan arang dan dioleskan disekitar pusar untuk menyembuhkan diare, Selain itu dapat digunakan untuk menyembuhkan luka dengan cara mengoleskan minyak kemiri yang didapat dari kemiri yang dibakar.digunakan juga sebagai penyubur rambut. Kandungan minyak dalam biji kemiri tergolong tinggi, yaitu $55-66 \%$ dari berat bijinya, mengandung asam lemak rantai panjang dan mengandung asam lemak tak jenuh yaitu asam oleat, asam linoleat dan asam linolenat ${ }^{(1)}$. Biji kemiri mempunyai biji yang keras bentuk bulat, diameter $2,5-3,5 \mathrm{~cm}^{(2)}$. Biji kemiri sering digunakan untuk mengobati bengkak, demam, kudis, pemeliharaan rambut, luka bakar dan sakit kepala. Pengobatan tersebut menggunakan kandungan minyak dari biji kemiri sebagai obat luar. Kandungan zat kimia dalam biji Kemiri yang diduga memiliki manfaat dalam penyembuhan luka bakar adalah saponin, flavonoida dan polifenol $^{(3)}$.

Penelitian tentang Kemiri telah dilakukan diantaranya Pengujian Penumbuh Rambut dari sediaan cair ekstraksi campuran Kemiri (Aleuritesmoluccana L.) dan kedelai (Glycine max (L.)Merrill) tidak menyebabkan iritasi ${ }^{(4)}$. Gel minyak biji kemiri (Aleurites moluccana) dengan konsentrasi $30 \% \mathrm{~b} / \mathrm{b}$ sudah menunjukan adanya efek menyembuhan luka sebanding dengan bioplacenton pada kelinci galur lokal ${ }^{(5)}$.

Berdasarkan penelitian yang telah dilakukan, peneliti tertarik untuk membuat suatu formulasi sediaan farmasi lainynya yaitu sediaan salep dengan variasi basis salep terhadap mutu sediaan salep minyak kemiri dan daya uji penyembuhannya terhadap luka terbuka pada kelinci yang terinfeksi bakteri Staphylococcus aureus.

Salep merupakan sediaan setengah padat yang ditujukan untuk pemakaian topikal pada kulit atau selaput lendir. Formulasi salep dibutuhkan adanya suatu basis,basis sendiri merupakan zat pembawa yang bersifat inaktif dari sediaan topical dapat berupa bentuk cair atau padat yang membawa bahan aktif untuk berkontak dengan kulit. Pemilihan basis salep yang tepat sangat penting karena basis salep mempengaruhi efek terapeutik dari suatu salep. Salep yang digunakan pada epidermis, mukosa, salep penetrasi atau bentuk cream memerlukan basis salep yang berbeda-beda. Kelarutan dan stabilitas obat di dalam basis, juga sifat luka pada kulit, menentukan pilihan dari pembawa sediaan semipadat. Basis salep dikelompokkan menjadi 4 kelompok besar yaitu basis hidrokarbon, basis salep absorpsi, basis salep tercuci air dan basis salep larut dalam air. Basis salep yang digunakan dalam suatu formulasi sediaan obat harus bersifat inert dengan kata lain tidak merusak ataupun mengurangi efek terapi dari obat yang dikandungnya $^{(6)}$. Berdasarkan hal tersebut maka perlu diteliti lebih lanjut pengaruh penggunaan basis salep terhadap daya antibakteri sediaan salep minyak kemiri terhadap penyebuhan luka kelinci

\section{BAHAN DAN METODE}

BAHAN. Biji kemiri, $n$-heksan teknis, alkohol 70\%, alkohol 96\%, Nutrien Agar (Oxoid), $\mathrm{NaCl} 0,9 \%, \mathrm{HCl}$ $0,1 \mathrm{~N}$, akuades, $\mathrm{H}_{2} \mathrm{SO}_{4} 0,36 \mathrm{~N}, \mathrm{BaCl}_{2} .2 \mathrm{H}_{2} \mathrm{O} 1,175 \%$, BHA, cera alba, metilparaben, propilparaben, $\mathrm{PEG}$ 400, PEG 4000, lanolin anhidrat, vaselin putih, aluminium foil, kelinci

METODE. Jenis penelitian ini ialah eksperimen laboratorium, menggunakan Rancangan Acak Lengkap (RAL) yaitu 4 (empat) perlakuan dan masing-masing perlakuan diulangi sebanyak 2 (dua) kali, dengan demikian jumlah kelinci yang digunakan yaitu sebanyak 4 ekor kelinci.

Persiapan Sampel. Sampel biji Kemiri sebanyak $2 \mathrm{~kg}$ dikumpulkan dan dibersihkan dari sisa kotoran (pengotor), selanjutnya dicuci dibawah air mengalir sampai bersih. Setelah bersih dari pengotor, sampel dikeringan dengan mengunakan oven pada suhu 400 ${ }^{\circ} \mathrm{C}$. Setelah itu, Sampel yang telah kering dihaluskan dengan menggunakan blender sampai menjadi serbuk. Hasilnya dimasukkan ke dalam wadah gelas tertutup.

Pembuatan Minyak Kemiri. Pembuatan minyak kemiri dilakukan dengan cara soxletasi dan destilasi. Serbuk buah kemiri yang digunakan sebanyak $250 \mathrm{~g}$ dengan pelarut $n$-heksan sebanyak $500 \mathrm{~mL}$. Proses destilasi dilakukan berulang hingga didapatkan minyak kemiri sebanyak 77,3536 g minyak kemiri

Formulasi dan Pembuatan Salep Minyak Kemiri. Formulasi sediaan salep Salep Minyak Kemiri dengan berbagai basis dapat dilihat pada Tabel 1.

Evaluasi Sediaan Salep Minyak Kemiri. Untuk memenuhi syarat pengujian salep, dilakukan beberapa pengujian diantaranya :

Uji Organoleptik. Uji organoleptik meliputi bentuk, warna, bau dari sediaan salep.

Uji Homogenitas. Uji homogenitas merupakan uji terhadap pencampuran bahan-bahan dalam suatu sediaan salep yang menunjukkan susunan yang homogen. Hasil uji homogenitas pada sediaan salep dikatakan homogen bila tidak terdapat partikelpartikel yang menggumpal dan juga mempunyai warna yang merata pada seluruh bagian salep ${ }^{(7)}$. 
Untuk dapat mengetahui sediaan salep homogen atau tidak dapat diketahui dengan mengambil sedikit dari sediaan dan digoreskan pada sekeping kaca atau bahan transparan lainnya

Uji pH. Uji pH dilakukan dengan menggunakan kertas indikator universal ataupun $\mathrm{pH}$ meter, dimana pH salep harus sesuai dengan $\mathrm{pH}$ kulit yaitu 4,5-6,5. Sebanyak 0,5 g salep Minyak Kemiri diencerkan dengan $5 \mathrm{ml}$ aquades, kemudian $\mathrm{pH}$ stik dicelupkan selama 1 menit. Perubahan warna yang terjadi pada pH stik menunjukkan nilai $\mathrm{pH}$ dari salep.

Uji Daya Sebar. Sebanyak 0,5 g salep diletakkan diatas kaca bulat yang berdiameter $15 \mathrm{~cm}$, kaca lainnya diletakkan diatasnya dan dibiarkan selama 1 menit. Diameter sebar salep diukur. Setelahnya, ditambahkan $100 \mathrm{~g}$ beban tambahan dan didiamkan selama 1 menit lalu diukur diameter yang konstan ${ }^{(8)}$.

Tabel 1.Formulasi sediaan salep minyak biji kemiri.

\begin{tabular}{lccc}
\hline & \multicolumn{3}{c}{ Konsentrasi basis $(\mathrm{g})$} \\
\cline { 2 - 4 } Bahan & Hidrokarbon & Absorbsi & Larut Air \\
\hline $\begin{array}{l}\text { Ekstrak } \\
\text { kental }\end{array}$ & 12,5 & 12,5 & 12,5 \\
BHA & 0,001 & 0,001 & 0,001 \\
$\begin{array}{l}\text { Cera alba } \\
\text { Metil } \\
\text { paraben }\end{array}$ & 2 & 3 & \\
$\begin{array}{l}\text { Propil } \\
\text { paraben }\end{array}$ & 0,01 & 0,01 & \\
$\begin{array}{l}\text { PEG 400 } \\
\text { PEG }\end{array}$ & & & \\
4000 & & & 6,02 \\
Lanolin & & & 17,6 \\
anhidrat & & 3 & \\
$\begin{array}{l}\text { Vaselin } \\
\text { putih }\end{array}$ & 85,489 & 81,480 & \\
& 100 & 100 & 100 \\
\hline
\end{tabular}

Penyiapan Hewan Uji dan Pembuatan Luka yang Terinfeksi Infeksi Bakteri. Hewan uji yang digunakan berumur 2-3 bulan dengan berat badan antara 1,2-1,5 kg. Sebelum pembuatan luka, kelinci terlebih dahulu diaklimatisasi selama 5 hari. Sehari sebelum pembuatan luka, hewan uji dicukur bulunya di daerah punggung sampai licin dan dibersihkan dengan alkohol $70 \%$, selanjutnya dibuat luka sayat dengan ukuran panjang $1,5 \mathrm{~cm}$ pada bagian punggung kelinci menggunakan pisau bedah sampai bagian subkutan. Suspensi bakteriS.aureus diberikan sebanyak 0,2 mL pada masing-masing lokasi. Pengamatan dilakukan setelah 24 jam untuk melihat adanya infeksi pada luka yang dibuat.

Perlakuan dan Pengamatan Luka. Kulit kelinci yang telah terinfeksi bakteri Staphylococcus aureus diberikan perlakuan dengan mengoleskan masingmasing 0,3 g sediaan salep Minyak Kemiri dan kontrol positif dengan perlakuan sebagai berikut :

Perlakuan A: Luka diberi Gentamicin salep (Kontrol Positif).

Perlakuan B: Luka diberi salep minyak kemiri dasar hidrokarbon.

Perlakuan C: Luka diberi salep minyak kemiri dasar salep absorbsi.

Perlakuan D: Luka diberi salep minyak kemiri dasar salep larut dalam air.

Sediaan salep diberikan dengan cara mengoleskan secara merata pada daerah luka tiga kali sehari. Kemudian dilakukan pengamatan setiap hari selama 8 hari, ukur diameter penutupan luka.

\section{HASIL DAN PEMBAHASAN}

Pembuatan salep dengan variasi dasar salep perlu dilakukan pengujian untuk mengetahui kelayakan salep tersebut untuk dapat digunakan sebagai obat pada bagian kulit. Pembuatan salep Minyak Kemiri dilakukan dengan cara sokletasi. Proses sokletasi dimaksudkan untuk menarik kandungan minyak Kemiri yang dikandung dalam biji Kemiri. Hasil sokletasi kemudiaan dilanjutkan dengan proses destilasi untuk menarik pelarut h-heksan yang masih tersisa. Dari hasil proses destilasi didapakan minyak kemiri sebanyak 77,3536 g.

Uji Organoleptik. Uji organoleptik dilakukan dengan melihat bentuk, warna dan bau dari sampel Salep Minyak Kemiri. Hasil organoleptik dapat dilihat pada Tabel 2. Berdasarkan pengamatan organoleptis variasi basis salep berpengaruh pada warna dan

Tabel 2. Hasil uji organoleptik.

\begin{tabular}{|c|c|c|c|}
\hline Jenis salep & Bentuk & Warna & $\mathrm{Bau}$ \\
\hline $\begin{array}{l}\text { SMK 12,5\% } \\
\text { Basis } \\
\text { hidrokarbon }\end{array}$ & $\begin{array}{l}\text { Setengah } \\
\text { padat }\end{array}$ & $\begin{array}{l}\text { Kuning } \\
\text { muda }\end{array}$ & $\begin{array}{l}\text { Khas } \\
\text { minyak } \\
\text { Kemiri }\end{array}$ \\
\hline $\begin{array}{l}\mathrm{SMK} \quad 12,5 \% \\
\text { Basis absorbsi }\end{array}$ & $\begin{array}{l}\text { Setengah } \\
\text { padat }\end{array}$ & $\begin{array}{l}\text { Kuning } \\
\text { muda }\end{array}$ & $\begin{array}{l}\text { Khas } \\
\text { minyak } \\
\text { Kemiri }\end{array}$ \\
\hline $\begin{array}{l}\text { SMK } \quad 12,5 \% \\
\text { Basis larut air }\end{array}$ & $\begin{array}{l}\text { Setengah } \\
\text { padat }\end{array}$ & $\begin{array}{l}\text { Putih } \\
\text { susu }\end{array}$ & $\begin{array}{l}\text { Khas } \\
\text { minyak } \\
\text { Kemiri }\end{array}$ \\
\hline
\end{tabular}

Ket : SMK : Salep Minyak Kemiri 
konsistensi, namun tidak berpengaruh pada bau. Bau dari salep minyak Kemiri yaitu bau khas minyak kemiri. Warna salep dengan basis hidrokarbon dan absorpsi cenderung kuning muda, sedangkan warna salep dengan basis larut air berwarna putih susu.

Uji Homogenitas. Sediaan salep dinyatakan homogen jika dasar salep, bahan aktif dan bahan tambahan lain tercampur merata. Hasil Uji dapat dilihat pada Tabel 3 .

Hasil pengamatan secara visual menunjukan susunan salep yang homogen, tidak mengumpal serta tidak terdapat butiran kasar, memiliki warna yang merata

Tabel 3. Hasil uji homogenitas.

\begin{tabular}{cc} 
Jenis salep & Homogenitas \\
\hline $\begin{array}{c}\text { SMK } 12,5 \% \text { Basis } \\
\text { hidrokarbon }\end{array}$ & Homogen \\
$\begin{array}{c}\text { SMK } 12,5 \% \text { Basis } \\
\text { absorbsi }\end{array}$ & Homogen \\
SMK $12,5 \%$ Basis larut & Homogen \\
air & \\
\hline
\end{tabular}

Ket : SMK : Salep Minyak Kemiri.

pada seluruh bagian salep. Berdasarkan teori, sediaan salep dikatakan homogen bila susunan partikel-partikel tidak ada yang menggumpal dan tidak tercampur. Hasil uji juga menunjukkan tidak ada perubahan homogenitas selama 4 minggu penyimpanan pada semua formula salep. Hasil tersebut menunjukkan bahwa variasi basis salep tidak berpengaruh pada homogenitas salep.

Uji pH. Pengujian pH sediaan salep harus disesuaikan dengan $\mathrm{pH}$ kulit manusia yaitu 4,5-6,5. Hasil pengukuran $\mathrm{pH}$ dengan menggunakan $\mathrm{pH}$ meter dapat dilihat pada Tabel 4. dibawah ini.

Berdasarkan hasil uji didapatkan $\mathrm{pH}$ salep Minyak Kemiri dengan ketiga basis yang sesuai dengan kulit

Tabel 4. Hasil uji pH.

\begin{tabular}{lc}
\multicolumn{1}{c}{ Jenis salep } & $\mathrm{pH}$ \\
\hline SMK 12,5\% Basis hidrokarbon & 5 \\
SMK 12,5\% Basis absorbsi & 5 \\
SMK 12,5\% Basis larut Air & 5
\end{tabular}

Ket : SMK : Salep Minyak Kemiri.

yaitu 4,5-6,5, sehingga aman untuk digunakan, karena $\mathrm{pH}$ yang asam akan mengiritasi kulit, sedangkan $\mathrm{pH}$ yang basa dapat menbuat kulit bersisik ${ }^{(6)}$.

Uji Daya Sebar. Daya sebar merupakan kemampuan penyebaran sediaan Salep Minyak Kemiri pada kulit. Daya sebar mempunyai korelasi dengan kemampuan penetrasi suatu zat kedalam stratum korneum $^{(9)}$. Hasil Uji Daya Sebar dapat dilihat pada Tabel 5.

Semakin besar daya sebar yang dimiliki suatu sediaan maka semakin tinggi kecepatan sediaan

Tabel 5. Hasil uji daya sebar.

\begin{tabular}{lc}
\hline \multicolumn{1}{c}{ Jenis salep } & $\begin{array}{c}\text { Daya Sebar } \\
(\mathrm{mm})\end{array}$ \\
\hline SMK 12,5\% Basis hidrokarbon & 4,5 \\
SMK 12,5\% Basis absorbsi & 5 \\
SMK 12,5\% Basis larutAir & 3,8 \\
\hline
\end{tabular}

Ket : SMK : Salep Minyak Kemiri.

salep menyebar pada kulit sehingga luas permukaan kulit yang bersentuhan dengan salep semakin besar pula. Pengujian daya sebar untuk setiap sediaan salep dilakukan untuk melihat kemampuan sediaan menyebar pada kulit, dimana suatu dasar salep sebaiknya memiliki daya sebar yang baik untuk menjamin pemberian bahan obat yang memuaskan. Urutan daya sebar salep dari yang terluas yaitu salep, basis absorpsi, basis hidrokarbon dan terakhir basis larut air. Daya sebar salep basis luas dikarenakan memiliki konsistensi yang lebih lembek dibanding dengan basis lainnya. Hasil pengujian dari ketiga sedian salep minyak kemiri dengan basis yang berbeda menunjukkan kemampuan Salep melewati membran. Semakin luas membran tempat sediaan menyebar maka koefisien difusi semakin besar yang mengakibatkan difusi obat pun semakin meningkat, sehingga semakin besar daya sebar suatu sediaan maka makin baik ${ }^{(10)}$. Minyak Kemiri basis absorpsi yang memenuhi syarat daya sebar. Perbedaan daya sebar sangat berpengaruh pada kecepatan difusi zat aktif dalam membran.

Uji Aktivitas Antibakteri Salep Minyak Kemiri 12,5\% dengan Variasi Basis Salep. Proses penyembuhan luka pada kelinci dengan ketiga variasi basis salep dapat dilihat pada Tabel 6. Proses penyembuhan luka ialah pengamatan terhadap penyembuhan luka pada kelinci yang telah diinfeksi bakteri S.aureus dan diolesi oleh salep minyak kemiri dengan tiga variasi basis salep. Proses penyembuhan pada luka disebabkan karena salep Minyak Kemiri mengandung berbagai komponen kimia yang berkhasiat sebagai antibakteri, diantaranya flavonoid, saponin dan polifenol. Dalam proses penyembuhan luka dibutuhkan senyawa yang dapat memacu pembentukan kolagen yaitu saponin, merupakan protein struktur yang berperan 
dalam proses penyembuhan luka. Flavonoid bekerja dengan mendenaturasi protein sel bakteri dan merusak membran sitoplasma, demikian pula saponin bekerja dengan merusak membran sitoplasma sedangkan polifenol bekerja dengan cara mendenaturasi protein dan mengurangi tegangan permukaan sehingga meningkatkan permeabilitas dinding sel bakteri(11). Salep dengan basis hidrokarbon cenderung memiliki daya hambat yang lebih kecil dibandingkan dengan basis lain karena basis hidrokarbon merupakan basis berlemak dimana mempunyai sifat lemak atau bebas air dan media pengujinyapun menggunakan nutrient agar yang cenderung mengandung banyak air sehingga salep yang mengandung zat aktif sukar untuk berdifusi atau melepaskan suatu zat aktif sehingga pelepasan zat aktifnyapun kurang maksimal. Basis salep hidrokarbon bertahan pada kulit untuk waktu yang lama sehingga memungkinkan larinya lembab ke udara dan sukar dicuci

Basis absorpsi memiliki daya hambat yang cukup bahan berlemak, sehingga dapat meningkatkan hidrasi dari stratum korneum dan meningkatkan penetrasi dari minyak kemiri. Efek hidrasi kulit yang meningkat akan meningkatkan absorpsi obat. Selain itu salep basis larut air mengandung PEG yang bersifat larut dalam air menyebabkan obat mudah terlepas dan terserap oleh kulit lebih cepat ${ }^{(12)}$.

Pada hasil pengukuran panjang luka infeksi pada setiap perlakuan dapat dilihat bahwa hasil yang diperoleh tidak berbeda signifikan, kecuali pada perlakuan kontrol negatif, dimana pada hari kelima luka masih belum sembuh total. Hal ini disebabkan karena tidak adanya bahan aktif yang terkandung didalam basis salep yang dapat menghambat pertumbuhan bahkan membunuh bakteri. Berbeda halnya dengan hasil pengukuran pada perlakuan control positif, dimana pada hari kelima panjang luka kelinci walaupun belum sembuh total.

Hasil pengamatan yang diperoleh dilanjutkan dengan analisis variabel secara sistematika

Tabel 6. Hasil pengukuran panjang penyembuhan luka pada kelinci dengan ketiga variasi basis salep.

\begin{tabular}{|c|c|c|c|c|}
\hline Hari Ke- & $\begin{array}{l}\text { SMK Basis hidrokarbon } \\
\qquad(\mathrm{mm})\end{array}$ & $\begin{array}{l}\text { SMK Basis absorbsi } \\
\qquad(\mathrm{mm})\end{array}$ & $\begin{array}{l}\text { SMK Basis } \\
\text { larut Air } \\
(\mathrm{mm})\end{array}$ & $\begin{array}{c}\text { Kontrol + } \\
(\mathrm{mm})\end{array}$ \\
\hline 1 & 1,5 & 1,5 & 1,5 & 1,5 \\
\hline 2 & 1,5 & 1,5 & 1,5 & 1,5 \\
\hline 3 & 1 & 1,5 & 1,5 & 1 \\
\hline 4 & 0,7 & 0,9 & 0,8 & 1 \\
\hline 5 & 0,6 & 0,7 & 0,6 & 0,9 \\
\hline 6 & 0 & 0 & 0,4 & 0,3 \\
\hline 7 & 0 & 0 & 0,3 & 0,2 \\
\hline 8 & 0 & 0 & 0 & 0 \\
\hline
\end{tabular}

besar karena basis ini merupakan basis yang dapat bercampur dengan air dengan jumlah tertentu, dimana basis ini mengandung lanolin anhidrat yang mana dapat bercampur dengan air dengan membentuk emulsi air dalam minyak sehingga basis absorpsi dapat melepaskan atau dapat berdifusi dengan cukup baik. Basis larut air memiliki daya hambat yang paling besar karena basis ini tidak mengandung bahan lemak dan mudah larut dalam air, karena basis salep ini mengandung PEG 400 dan PEG 4000 yang merupakan basis salep yang tidak berlemak sehingga dapat bercampur dengan media uji nutrien agar yang bersifat polar dan dapat berdifusi dengan baik. Basis larut air terdiri dari fase air dan tidak mengandung menggunakan uji statistik ANOVA. Hal ini dimaksudkan untuk melihat apakah ada efek dari tiga variasis basis salep perlakuan terhadap penyembuhan luka yang infeksi bakteri dengan data yang lebih spesifik dan signifikan secara sistematik. Dalam pengujian ANOVA diperlukan hipotesa data dimana $\mathrm{H}_{0}$ tidak ada perbedaan panjang luka pada kelinci dan $\mathrm{H}_{1}$ adanya perbedaan panjang luka pada kelinci dengan taraf signifikan ( $\alpha=0,05$ atau $5 \%$ ). Untuk pengambilan keputusan yang didasarkan pada perbandingan $\mathrm{F}$ hitung dan $\mathrm{F}$ tabel dengan persyaratan jika F hitung lebih kecil dari $\mathrm{F}$ tabel maka $\mathrm{H}_{0}$ diterima dan jika $\mathrm{F}$ hitung lebih besar dari $\mathrm{F}$ tabel maka $\mathrm{H}_{0}$ ditolak. 
Hasil dalam pengujian ANOVA dengan menggunakan uji $\mathrm{F}$ menunjukkan nilai $\mathrm{F}$ hitung sebesar 0,116 dan sig. 0,950. Dapat disimpulkan hasilnya signifikan $(\mathrm{p}>0,05)$, hal ini menunjukkan bahwa perbedaan basis tidak berpengaruh terhadap uji penyembuhan luka terbuka pada tikus. Selanjutnya dilakukan uji LSD hasilnya signifikan $(p>0,05)$ antara ketiga basis. Dengan dapat disimpulkan $\mathrm{H}_{0}$ diterima.

\section{SIMPULAN}

Ketiga formula salep dengan variasi basis salep minyak kemiri 21,5\% memenuhi mutu sediaan salep meliputi uji mutu sediaan salep, organoleptik, homogenitas, $\mathrm{pH}$, tetapi tidak memenuhi daya sebar untuk salep dengan basis larut air. Ketiga variasi basis salep minyak kemiri $12,5 \%$ memenuhi daya penyembuhan terhadap luka pada kelinci yang terinfeksi bakteri Staphylococcus aureus.

\section{UCAPAN TERIMA KASIH}

Terimakasih kepada Universitas Sam Rutalangi atas dana yang diberikan pada skim riset dasar unggulan UNSRAT dengan nomor kontrak 1872/UN12.13/ LT/2018.

\section{DAFTAR PUSTAKA}

1. Ginting M, Surbakti D, Thamrin. Sintesis dan karakteristik senyawa polihidroksi yang diperoleh melalui epsoksidasi minyak kemiri. Jurnal Penelitian MIPA. 2008. 2 (1) 1

2. Krisnawati, H. Kallo.M dan Kanninen. M.. Aleurites moluccana (L) Willd. Ecology. Silviculture and Prodictivity. CCIFOR.Bogor. Indonesia. 2011. Hal 1-4
3. Heyne K, 1987. Diambil dari: URL: https://id.wikipedia. org/wiki/Kemiri. Diakses tanggal 15 Agustus 2018.

4. Izemi1, B. Boy Rahardjo Sidharta, Yanuartono. Potensi Sediaan Cair Ekstrak Campuran Kemiri (Aleurites moluccana L.) dan Kedelai (Glycine max (L.) Merill) sebagai Penumbuh Rambut. e-journal.uajy. ac.id/8622. 2015. Hal 1-11

5. Richa Yuswantina, Istianatus Sunnah dan I Nyoman Dwika Dharmanta. 2014. Diakses tanggal 3 Agustus 2018. Kode Jurnal: jpfarmasidd140494.

6. Pongsipulung Grace. 2013..diambil dari URL:https:// ejournal.unsrat.ac.id/index.php/pharmacon/article/ view/462/370. Diakses tanggal 2 Agustus 2018.

7. Lachman, Leon. Teori dan Praktek Farmasi Industri. UI-Press : Jakarta. 2008.

8. Astuti I. Y., D. Hartanti, dan Aminiati A. Peningkatan Aktivitas Antijamur Candida albicans Salep Minyak Atsiri Daun Sirih (Piper bettle LINN.) melalui Pembentukan Kompleks Inklusi dengan $\beta$-siklodekstrin. Majalah Obat Tradisional. 2010. Hal 94-9

9. Akhtar. N.,Adnan, Q.Ahmad, M. Mehmood,A.,Farzana, $\mathrm{K}$. Rheological studies and characterization of different oil. J. Chem. 2009. Soc.Pak.31(2).Hal. 201-6

10. Hasyim. N. K.L, Pare. I, Junaid, Kurniati A. Formulasi dan Uji Efektivitas Gel Luka Bakar Ekstrak Daun Cocor Bebek (Kalanchoe pinnata L.) pada Kelinci (Oryctolagus cuniculus). Majalah Farmasi dan Farmakologi. 16(2) : 2012. Hal 89-94

11. Ginting, M. Surbakti, D, Thamrin. Sintesis dan Karakterisasi Senyawa Polihidroksi yang diperoleh melalui Epoksidasi Minyak Kemiri. Jurnal Penelitian MIPA (2) . 2008. 1.1

12. Naibaho. H. Olivia. 2013. Diambil dari https://ejournal. unsrat.ac.id/index.php/pharmacon/article/view/1553. Diakses tanggal 30 Mei 2018. 